\title{
O SONHO E A EXPRESSÃO ESTÉTICA DA CONTRADIĢÃO
}

\author{
Ricardo Prado Pupo Nogueira
}

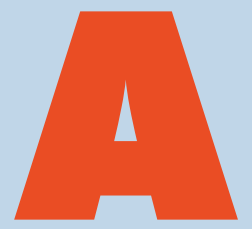

antropologia e a psicanálise possuem seus próprios terrenos de estudo. Porém, não se pode deixar de perceber, que tanto uma forma de conhecimento, como a outra, enfoque o homem e sua relação com o mundo. Não o mundo concreto e objetivado, mas o mundo que vai se destacando e aos poucos se revelando do que até então era abstrato ou desconhecido. Mas, mesmo sendo desconhecido, manifesta-se com impositiva autoridade, justificando seu reconhecimento. A capacidade humana de criar seus caminhos sob as condiçôes naturais, marca sua trajetória na posse do conhecimento e de seu consequente desenvolvimento. Por meio das dificuldades de adaptação ao meio ambiente, o homem pode descobrir suas ferramentas internas, para se organizar dentro dessa estrutura complexa das leis naturais. $\mathrm{O}$ homem foi se integrando dentro de sua possibilidade de elaboração dos princípios naturais que o cercam, e dessa integração surgiu a chance da espécie. A percepção das limitações encontrou, em nossa espécie, um poder de superação até então inusitado para as espécies anteriores, o que nos tornou mais credenciados a uma adaptação eficiente. Tal crédito inicia-se com o que se costumou chamar de pensamento primitivo e faz referência às características das culturas primitivas e a estrutura de seu funcionamento. O termo primitivo aqui se refere a como no início do nosso desenvolvimento o conhecimento era estruturado e organizado. A posse do conhecimento, nessa época, seguia padrōes intuitivos e levaram muitos e muitos anos para chegar a critérios mais lógicos e definidos. Não existe em tal constatação funcional nenhuma desvalorização, mesmo que hoje o privilégio científico seja da maior importância. Na verdade, todos os recursos são necessários para a evolução da espécie. O fato é que atualmente o conhecimento que preliminarmente chamaremos de intuitivo, para depois defini-lo melhor, fica relegado a planos secundários e até mais identificado com um pensamento pueril e inconsistente, que de forma nenhuma se justifica, pois o intuitivo, ou, se preferirem, o primitivo é a base do que futuramente poderá ser lógico e científico. A desatenção atual sobre esse descrédito provém da confusão entre produto e produção. Privilegia-se o resultado, deixando num segundo plano suas organizaçōes produtivas, desprezando assim a criatividade significante que nos tirou das trevas e das cavernas. A desatenção para a base criativa do processo supervaloriza o significado final, que poderia ser chamado de conhecimento específico. No esforço de controlar o conhecimento, o homem se descuidou do abstrato e de sua força expressiva, mesmo que ainda não totalmente compreendida. Forma-se assim uma zona de conforto e de falso controle. Digo falso, porque a adaptação ao mundo se faz na mesma proporção em que ele é transformado. A capacidade de integrar-se 
até para o que foi criado por ele mesmo, é o que permite ao homem não acabar sendo vítima de suas próprias ações.

A estrutura do funcionamento onírico é o tema encontrado neste estudo, para o resgate essencial do pensamento primitivo. Para que essa operação possa ser feita, vou apresentar o sonho como outro polo perceptivo, que se integra em todas as características essenciais da teoria da percepção. No sonho sentimos intensamente sua expressão, mas não conseguimos compreendê-lo na mesma proporção. Por mais que Sigmund Freud tenha se esforçado para entender seu funcionamento, e descoberto sua origem inconsciente; e por mais que outros autores que vieram depois dele, como Melanie Klein, Wilfred Bion e Jaques Lacan, aprimorassem esse conhecimento, o valor que damos a ele ainda é desproporcional à sua importância.

A psicanálise desvirtualizou o inconsciente, reconhecendo nele a capacidade significante até então incompreendida A antropologia também trilhou um caminho semelhante e passou a perscrutar os signos e a se ocupar deles, originando um vasto campo de significância. Na verdade, as duas formas de conhecimento foram se ocupando, cada uma a seu modo, dos contornos formais do que nos é imposto a partir do inconsciente, e das consequências de sua ação na adaptação ao mundo. Se a antropologia buscou a estrutura dos movimentos sociais das sociedades primitivas, a psicanálise buscou, por seu lado, a força expressiva do inconsciente, sua linguagem e consequentemente sua leitura. Caminhando assim, paralelamente, essas duas formas de conhecimento foram descobrindo o conceito de "significante" e entendendo que se poderia sentir o que ainda não era conhecido.

No que se refere à antropologia, Bronislaw Malinowski (1) foi o primeiro a tatear esse caminho. Seu conceito de maná cunhado a partir do conhecimento das trocas, e de sua importância entre os membros das comunidades primitivas, começa a reconhecer a transcendência de tais mecanismos que evocavam um poder de operação nas estruturas sociais. Não apenas se dava um presente, mas se adquiria um poder sobre o outro, como se o interior do presente contivesse uma força mágica, religiosa ou espiritual. Esse conceito, desenvolvido posteriormente por Lévi-Strauss (2), ganha outra dimensão. Para ele, o conceito de maná não pertence à realidade e sim ao pensamento, que quando pensa em si, só pode pensar em um objeto. Reconhece-se assim que os significantes só significam, sem que tenham que ter um significado próprio. Um significante é vazio de significado, e é apto apenas a criar novos significados. O maná é esse significante que representa os infinitos significantes vazios, aptos a gerar significados. O significante opera as forças expressivas organizando-as numa coerência estética, para produzir um significado, que por sua vez representa expressivamente as composiçōes de força que lhe deu origem.

A psicanálise caminhou de forma semelhante e procurou entender as expressões humanas, em sua coerência interna, o que revelaria a participação de forças fora da consciência, até então desconhecidas, ou, apenas, intuídas. Observa-se que são caminhos semelhantes, em que se procura o até então abstrato, mas atuante, poder de síntese de expressōes, até mesmo contraditórias, mas que, apesar da contraditoriedade, não perdem o compromisso com a verdade. Não a verdade normativa, das leis e dos regimes, mas a verdade de se estar no mundo, a verdade do real inatingível, mas orientador, em direção ao qual caminha o sentido seguro da significação. Não posso deixar de ressaltar aqui a imensa contribuição da teoria semiótica sobre o que se considera um signo verdadeiro (3). Esse conceito nos ensina, exatamente, a importância do compromisso sígnico em direção ao real, que por ser inatingível, existe apenas como um rumo seguro do signo, como se desse a ele seu DNA de verdade. Isso não quer dizer que o signo seja definitivo, quer dizer apenas que suas mudanças se produzem na busca desse real. Sua autenticidade não está em sua verdade, e sim na transformação evolutiva, que leva em conta todas as infinitas mudanças a que estamos sujeitos, contanto que a percepção do real continue orientando sua evolução.

O que não se deve perder de vista é o quanto somos definidos pelos arranjos que se faz em nosso interior, sem que conscientemente tenhamos notícias deles. Sentimos seus efeitos e somos muitas vezes impulsionados por determinaçōes que chegam a nos surpreender. Estou falando como se me referisse a um polo perceptivo que integra os achados e apenas inicia sua organização, esperando que, posteriormente, eles possam ser mais bem definidos. Esse é o verdadeiro papel do significante. Ele é o grande explorador da massa incomensurável que nos envolve. Ele é um componente importante do aparelho perceptivo que ainda não sofreu a redução linguística, e que, portanto, concentra um alto teor de informação bruta, indiferente às contradiçōes internas do padrão linguístico. Prescindindo da redução necessária ao funcionamento da língua, o percepto ainda bruto, ganha as portas da compreensão por meio da estética formal.

O sentido estético pressupõe que tudo que é expresso é virtualmente conteúdo tal como forma. Como forma, devo definir aqui, a coerência estética de todo fenômeno particular. Isso quer dizer que as contradiçôes são nela imediatas e excluem-se entre si. Assim, chega-se ao sentimento estético, que é o de ser totalmente dominado pelo ininteligível e, no entanto, definido. É, exatamente, o que percebemos nos movimentos sociais, nos lapsos e, principalmente, em nossos sonhos.

Das possibilidades citadas escolherei a que para mim é a mais significativa. Estarei falando do sonho, da estrutura do sonhar, de sua forma muito particular de expressão que até hoje nos intriga. A estrutura do sonhar tem um sentido maior do que uma resolução de conflito, função essa que está mais associada à consciência. O sonho se presta a encontrar uma linguagem para esse conflito. De acordo com o que está sendo desenvolvido aqui, podemos transcender as questôes referentes ao sonho como apenas uma realização de desejo, e chegar assim a um formalismo estético; à natureza esteticamente construtiva da contradição, sem que seja ainda atrofiada por nosso rigor conceitual. Como dizia Friedrich Hegel: "A arte é a expressão da verdade". Pensando assim, abre-se o caminho para a primeira instância do processo perceptivo. Se os significados são caminhos seguros para a procura da verdade, porque a expressão conflitiva também não seria? Sendo que os significados se originaram desse primeiro movimento perceptivo? Eu até poderia dizer que construímos o mundo que vivemos pelo sentido, mas o alimentamos pela expressão da contradição. Assim, podemos explicar o horror com que 
acordamos, em alguns momentos, de sonhos angustiantes e o tempo que levamos para apaziguar a mente, e transformar o vigor expressivo num discurso mais brando e controlado. Essa pequena fração de nosso dia era extremamente dilatada nas culturas primitivas que se defrontavam com leis naturais tão impiedosas e até então desconhecidas no seu cotidiano. Esse horror foi sendo enfrentado com a condição significante que foi evoluindo e trazendo uma compreensão e recursos para a nossa evolução na história do mundo. Mas, a sensação frente ao inusitado que ainda hoje é sentida, e que acredito, nunca desaparecerá, está aí para que possamos explorá-la com mais recursos de significantes capacitados a gerar novos significados.

Theodor Adorno (4) apreende maravilhosamente o que está sendo dito aqui: "O horror e o belo apenas parecem contraditórios, mas são apenas sensaçôes frente ao inusitado”. Na mesma obra, um pouco mais à frente, surge outro ponto que reforça a importância da expressão estética da contradição: "A dor na presença do belo é a nostalgia do que é interdito ao sujeito pelo bloco subjetivo, mas mesmo que interdito é mais verdadeiro do que ele próprio".

Freud (5) revelou a importância da satisfação do desejo na organização onírica. Ligado ao princípio do prazer esse seria, segundo ele, a mola mestra na concepção das cenas preconizadas nos sonhos. Sem que se deixe de lado a sua importante descoberta, estou transcendendo as barreiras do prazer, para abranger o conhecimento, e a consequente instrumentação que ele nos proporciona frente ao inusitado e, até então, insondável. A expressão criativa é capaz de vencer a barreira das contradições, e salvar parcelas do real que poderiam ficar, para sempre, soterradas. Isso explica a sensação íntima que temos com nossos sonhos, que por mais estranhos que possam parecer, guardam uma noção muito profunda de identidade. Estamos convictos de que o sonho foi produzido em nosso interior, só não conseguimos acompanhar completamente as etapas de sua criação.

Se os sentidos são caminhos seguros para a procura da verdade, porque desprezaríamos sua expressão, ainda que estranha ao nosso conhecimento? Deve-se entender que o conflito é resultante não da natureza essencial da coisa em si, mas sim da forma que organizamos seu conhecimento. Portanto, o que chamamos de conflito, é resultante do conhecimento com que objetivamos a coisa em si mesma e, sendo assim, só pode ser corrigido originalmente por meio do desenvolvimento perceptivo que, no meu entender, é o que os sonhos podem fazer. Isso porque a estrutura do sonhar se apresenta como formalização estética para as contradições. Dessa maneira, a estrutura do sonhar está mais próxima do polo perceptivo, enquanto a linguagem discursiva está na ponta final do processo e faz a apresentação do significado. Como estamos muito mais acostumados com a linguagem discursiva, acabamos, erroneamente, por valorizá-la pelo todo de um processo de significação, que começa na essência primordial da coisa, captada perceptivamente e reconhecida sob uma determinada forma que chamamos de significado. O que não podemos esquecer é que esse significa- do é apenas uma das infinitas formas de reconhecimento da coisa propriamente dita, que sempre estará além da nossa objetivação formal. Como dizia Immanuel Kant: "O conhecimento discursivo deve renunciar ao íntimo das coisas".

Theodor Adorno (6) tem uma forma muito simples e original de apresentar a importância do significante e da constituição esteticamente formal da contradição. Para o autor, a arte tem o dom de preservar o estético e manter a percepção ativa com o ainda indefinido. Falando da arte, pode-se compreender melhor, por meio da teoria estética de Adorno, porque somos cativados por formas que nos envolvem e sensibilizam sem que necessariamente saibamos por quê. Acrescento que o mesmo acontece com os sonhos, que com suas composições de imagem, nos atingem profundamente. Vale aqui a citação original de Adorno: "As obras de arte representam as contradiçôes enquanto um todo, a situação antagonista enquanto totalidade. Só através da sua mediação, não mediante o seu parti pris direto, é que são capazes de, graças à expressão, transcender a situação antagonista. As contradições objetivas sulcam o sujeito; não são por ele postas, nem produzidas pela sua consciência. Eis o verdadeiro primado do objeto na composição interna das obras de arte. $\mathrm{O}$ sujeito pode dissolver-se frutuosamente no objeto estético só porque ele é, por seu turno, mediatizado pelo objeto e exprime, ao mesmo tempo, de modo imediato, o sofrimento. Os antagonismos são tecnicamente articulados na composição imanente das obras, que torna a interpretação translúcida às relações de tensão no exterior. As tensões não são copiadas, mas dão forma à coisa; só isto constitui o conceito estético da forma".

A contradição apreendida numa estética formal, reforça a importância de conceitos aparentemente esquecidos, como, por exemplo, o de maná, inicialmente estudado por Malinowski e Lévi-Strauss, e, atualmente, só relacionado a um momento primitivo de nossa cultura. A condição significante nunca deixou de ser vital para nossa cultura e seu desenvolvimento. Sua apreciação estética nos deixa mais próximos da sondagem do abstrato e de novos caminhos da significação. A prova do que acabou de ser dito está nos sonhos, que nunca desapareceram e não deixaram de ter a mesma estrutura de funcionamento, desde os tempos mais remotos, de onde nos vem relatos ainda hoje pesquisados. Sendo assim, a estrutura onírica pode ser reconhecida como um polo perceptivo, plenamente adaptado aos conceitos da teoria da percepção. Os sonhos adquirem dessa maneira uma importância maior na expressão criativa de recursos que não poderiam se apresentar à nossa consciência de outra maneira, posto que a comunicação linguística não é um instrumento apto para a manifestação contraditória formal. A estrutura onírica se presta a essa liberdade significante que, por sua vez, nos aproxima do percepto ainda livre das restrições comunicacionais impostas pela linguagem. Isto até nos explica porque nos tempos modernos, tão tecnológicos e científicos, os rituais primitivos e mágicos, continuem sendo procurados e estudados. A adaptação humana ao mundo continua dependente desse recurso, da mesma forma como as cul- 
turas primitivas. Se existe uma diferença, ela está apenas na grande quantidade de significados que foram gerados no desenvolvimento da espécie humana. Não podemos, com tanta sabedoria acumulada, desprezar os elementos primitivos de nossa cultura, atualizados em nossos sonhos e na arte, que apesar de ser moderna, procura resgatar nossos primeiros momentos de evolução social e cultural. Segundo Boris Groys (7), a grande característica da arte moderna é a de levantar uma suspeita, suspeita essa que nos remete a uma pergunta tão comum que nos fazemos frente a algo inusitado que nos atinge emocionalmente sem que saibamos bem por quê. A pergunta é: $\mathrm{O}$ que seria isto que está sendo observado? A arte moderna nos retira a segurança da definição e abre a via da suspeita e da criação. Com a sutileza, própria dos artistas, a arte moderna recupera a insegurança criativa frente ao mundo aplicada às culturas primitivas, por meio de rituais mágicos e sagrados. O sonho, outro baluarte do império significante é respeitoso frente a suas imagens contundentes e profundamente realistas, aptas a abrir a capacidade criativa.

Ricardo Prado Pupo Nogueira épsiquiatra, psicanalista e doutor em comunicação e semiótica pela Pontificia Universidade Católica de São Paulo (PUC-SP).

\section{REFERÊNCIAS BIBLIOGRÁFICAS}

1. Malinowski, B. Uma teoria científica da cultura. Rio de Janeiro: Editora Zahar. 1975.

2. Lévi-Strauss, C. As estruturas elementares do parentesco. Petrópolis: Vozes. 1976.

3. Santaella, L. A Assinatura das coisas. Peirce e a literatura. Rio de Janeiro: Editora Imago. 1992.

4. Adorno, T. W. Teoria estética. Lisboa: Edições 70. pp. 401-475. 2008.

5. Freud, S. Interpretação dos sonhos. Vol. IV, Tomo VI. Rio de Janeiro: Delta. 1979.

6. Adorno, T. W. Teoria estética. Lisboa: Edições 70. p. 492. 2008.

7. Groys, B. Bajo sospecha. Uma fenomenologia de los medios. Valencia: Editora Pre-textos. 2008. 